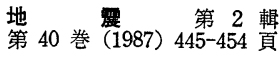

\title{
生野地学観測室における自然極微小 破壊の観測（1）
}

\author{
京都大学理学部地球物理学教室 小笠原 宏・藤 森 邦 夫
}

(昭和 62 年 6 月 10 日受理)

\section{Observations of Natural Ultramicro-Fracturings at Ikuno Geophysical Observation Station (1)}

\author{
Hiroshi Ogasawara and Kunio FuJImoRI \\ Geophysical Institute, Kyoto University
}

(Received June 10, 1987)

Since February 1985, we have observed natural ultramicro-fracturings occurring in an area of several tens square meters at Ikuno Geophysical Observation Station in Hyogo Prefecture. From the present observation, we have attempted to obtain an adequate idea of the mechanism of the anomalous crustal deformation: it was recorded only by the extensometer No. 4 at this station before and after the Yamasaki fault earthquake $(M 5.6 ; \Delta \doteqdot 30 \mathrm{~km})$ on May 30, 1984. The Observation system was designed to detect an event occurring near the extensometer No. 4 with frequencies of $100 \mathrm{~Hz}-30 \mathrm{kHz}$ and an amplitude larger than 30 gals. Another anomalous crustal deformation was recorded only by the same extensometer No. 4 in October-November 1985. The events that could be regarded as ultramicro-fracturings were observed in this period. The larger one had a predominant frequency of about $3 \mathrm{kHz}$ and a maximum amplitude greater than 50 gals. This event was observed only by the sensor near the interface between rhyolite and tuff across which the extensometer No. 4 was installed. The other was observed by two sensors also near the interface. It can, therefore, be thought that the sources of these events are near this interface and that the anomalous crustal deformation and the natural ultramicro-fracturings are probably caused by local slips on this interface. This view, however, requires more data to be investigated and confirmed.

\section{§1. はじめに}

1984 年 5 月 30 日の山崎断層地震 $(M 5.6)$ 前後から, 兵庫県朝来郡生野町の生野地学観 測室に招いて異常な地殼変動が観測された [藤森・他 $(1984,1985)]$. この変動は, 同観測室 に設置されている複数の計器に同時に現れたものではなく，凝灰岩と流紋岩との接触面をまた ぐ伸縮計 4 番のみに顕著に現れたものであった．藤森・他 $(1984 ， 1985)$ は，この接触面に括 ける局所的なスリップが，観測された異常地殼変動の直接的な原因であると考无た。しかし， 観測をただ継続するだけでは，このよらな異常地殼変動がもし再び観測されたとしても，藤 森・他 $(1984 ， 1985)$ の考学を検証できる可能性は薄いと思われた。 また，異常地殼变動の原

昭和 61 年 4 月 4 日発表 
因に関するより多くの情報を得るためには，同じ観測坑内のしかるべき位置へ地殼変動観測計 器を増設するか, あるいは, 地殼変動に関連する他の現象の同時並行観測を新たに始めること が必要であった。 もし，局所的なスリップが生じているならば，微小破壊が同時に発生してい る可能性がある.また, 異常地殼変動に関する情報がこの観測から得られなかったとしても, 微小破壊と地殼変動との同時並行観測から新しい知見が得られる可能性もある.このような動 機で自然極微小破壞の観測を生野地学観測室において行らことにした.

同観測室においては，どこでどの程度の振幅，卓越周波数の振動を捉觉ることができるかと いら事前の情報が全くなかったため，とりあえず，飯尾（1984）が中竜鉱山において捉えたも のと同規模の微小破壞 （振幅 数gal 数十gal, 周波数 $100 \mathrm{~Hz} \sim 30 \mathrm{kHz}$ の振動）を捉光るこ とができるように観測システムを設計した。 1985 年 2 月に予備観測を行った後，1985 年 3 月にイベント計数観測を開始し [小笠原・藤森 (1985)]， 1985 年 7 月から波形観測を開始し た. 1985 年 10 月から 11 月にかけて伸縮計 4 番に顕著な異常地殼変動が再び観測された. 微小な破壞によって発生したと思われる振動が，少数ではあるが，これと同時期に捉えられた。 これらは, 発破等の人工的な原因によって岩盤応力が時間的に急変したために発生したもので はなく，また，飯尾（1984）によって捉えられた微小破壊の小さいものと同程度，あるいは， それよりも小さいと思われるので，自然極微小破壊と呼ぶことにする. 本論文では 1985 年 7 月から 1986 年 2 月までの観測の概要と観測システム，ノイズとその対策，そして上記のイ ベントについて報告する.

\section{$\S 2 . \quad$ 自然極微小破壊の観測}

\section{1. 生野地学観測室}

生野地学観測室は, 旧生野鉱山域内の金香瀬山（標高 $700 \mathrm{~m}$ ) 中腹の旧火薬庫坑内（地表か

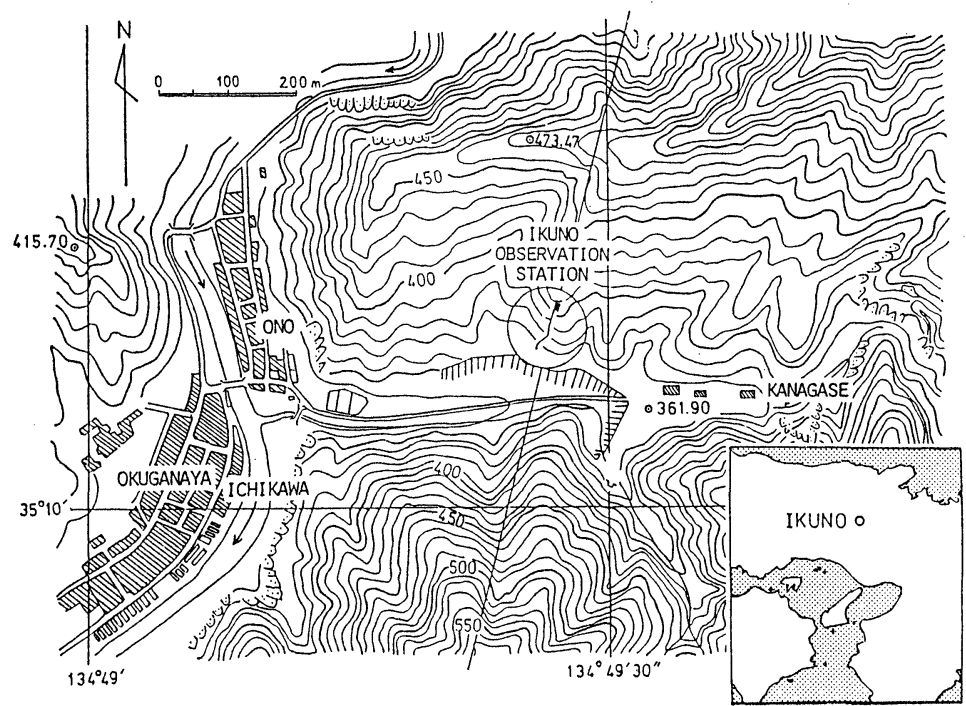

Fig. 1. The location of Ikuno Geophysical Observation Station [after $\mathrm{T}_{\mathrm{ABEI}}$ et al. (1985)]. 
らの深度は約 40 m; Fig. 1) に, 1976 年に開設され，地殼变動と気象等の観 測が行われている [田部井・他 (1985)]. 生野鉱山は 1973 年に閉山され，1986 年現在, 応力場を短時間内に急変させ らる人工的な要因は観測室付近にはな い(発破が行われているのは約 $1 \mathrm{~km}$ 西方の採石場のみ)。 また，最も近い 旧鉱区から約 $500 \mathrm{~m}$ 離孔て扣り，観 測室付近の静的応力場が，採鉱跡など によって大きく乱されていることもな いと思われる．観測坑内の岩盤は, 藤 森・他 (1984) が言ら岩体接触面を境 にして, 坑口側が流紋岩, 坑道奥側が 凝灰岩からなる (Fig. 2).

\section{2. 観測システム}

2 種類のプリアンプ内蔵の圧電型加 速度計をセンサーとして併用した. 一 方は， $30 \mathrm{kHz}$ まで特性が平坦である が感度は低いもの $(\mathrm{TEAC} / \mathrm{bbn}$ 社 $508 \mathrm{~B} ; 10 \mathrm{mV} / \mathrm{G}$; 以下, 単に「低感 度センサー」), 他方は, 特性が $10 \mathrm{kHz}$

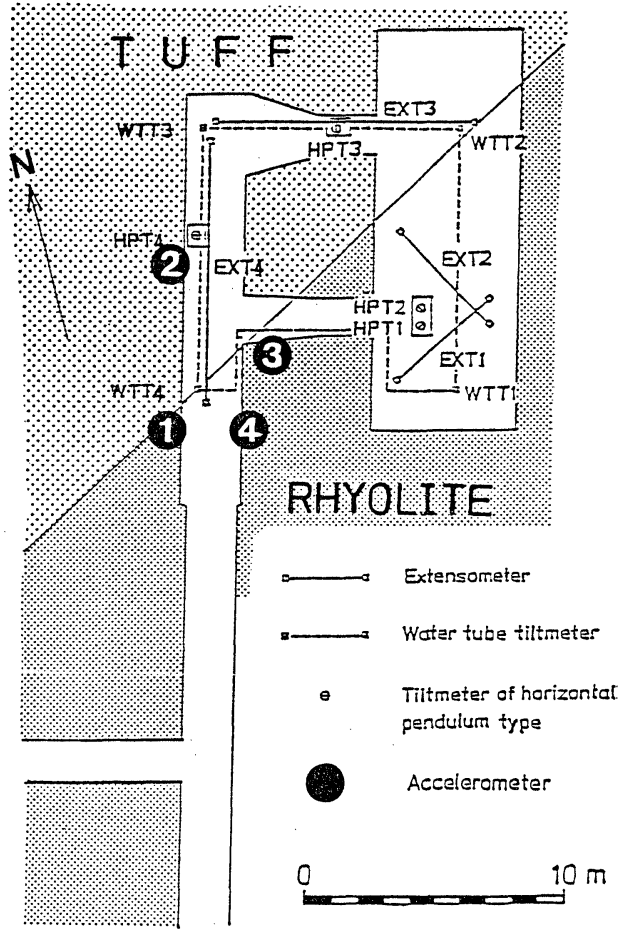

Fig. 2. The observation tunnel and the arrangement of instruments [modified after $\mathrm{T}_{\mathrm{ABEI}}$ et al. (1985)]. までしか平坦でないが感度が高いもの (TEAC 社 707；100 mV/G；以下，単に「高感度センサー」) である.

亀裂の多い場所や浮き石では高周波成分の減衰が激しいため，このような地点を避け，セン サーは直接岩盤に石亳で固定した。 また，空気中を伝わる音波に共鳴しないように，ケーブル もセンサー付近約十 $\mathrm{cm}$ は石膏で固定した。ロックハンマーで岩盤をたたいたときに生じる 振動を全点で補捉しうる範囲内で，互いにできるだけ離れるように，3 個の低感度センサーを 数 $\mathrm{m}$ 間隔で岩体接触面付近に設置した。観測点 1 および 3 に設置したセンサーは 1985 年 3 月から 1986 年 2 月まで位置を変えなかった。 観測点 2 に設置したセンサーは, 1985 年 12 月までの間にイベントが全く捉えられなかったため，1985 12 年月に観測点 3 から約 $1 \mathrm{~m}$ 坑 口側の地点に移設した．第 4 のセンサーは，場合と目的に応じて感度や設置箇所を変えた.

観測システムのブロック図を Fig. 3 に示す。 センサー，アンプ，パーソナルコンピュータ， ウェーブメモり以外は手作りである. センサーの出力は, 坑内で 1,000 倍に増幅され（アンプ は TEAC 社 SA-16; 周波数特性 $0 \sim 50 \mathrm{kHz},+1 \mathrm{~dB},-3 \mathrm{db}$ ) 同軸ケーブルで坑外へ送られ る. 坑外では，信号は， $f_{c}=50 \mathrm{kHz}$ のバタワース型 5 次のローパスフィルターを通された後， トリガー判定される.フィルター出力中の定常的な電気的バックグラウンドノイズレベルは, 約 $50 \mathrm{mV}$ p-p である. これは加速度に換算すると, 低感度センサーおよび高感度センサーに対 し，それぞれ，5 拈よび $0.5 \mathrm{gal}_{\mathrm{p}-\mathrm{p}}$ である. また時々 $300 \mathrm{mV}$ を超える突発的な電気ノイズ 


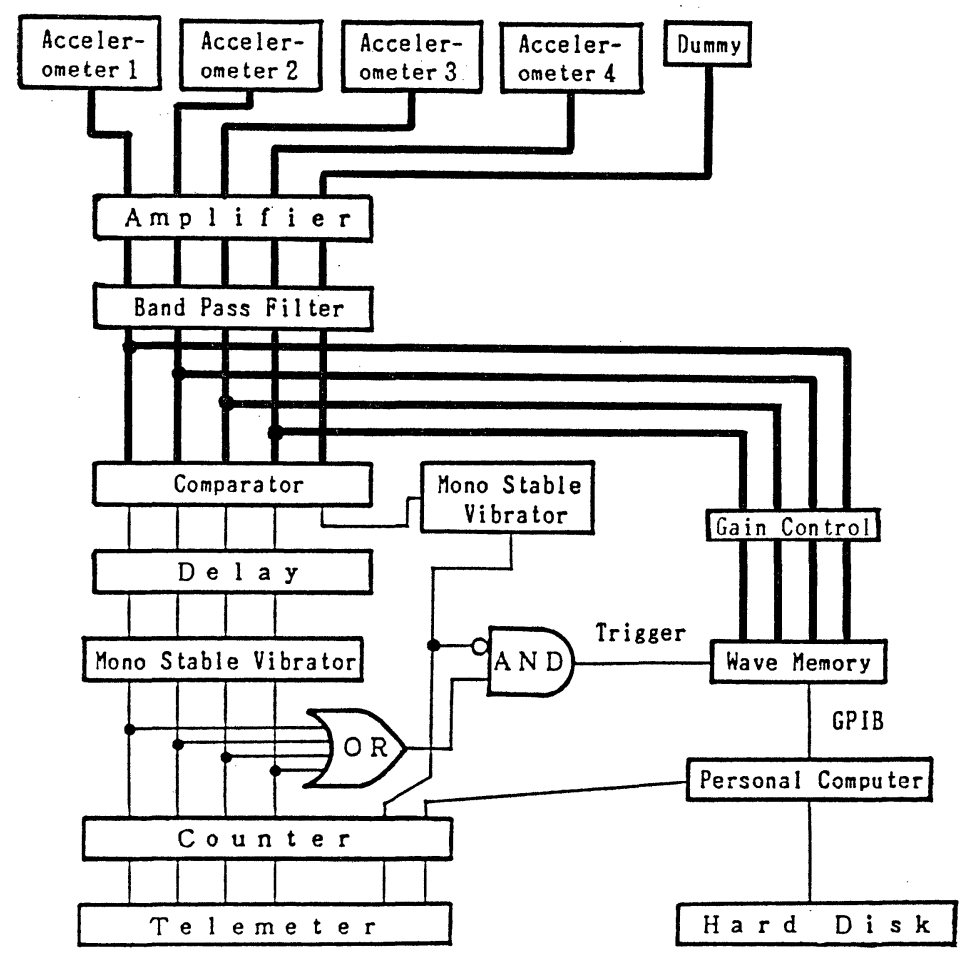

Fig. 3. A block diagram of the observation system of natural ultramicro-fracturing. The analog and digital signal lines are shown by thick and thin lines, respectively.

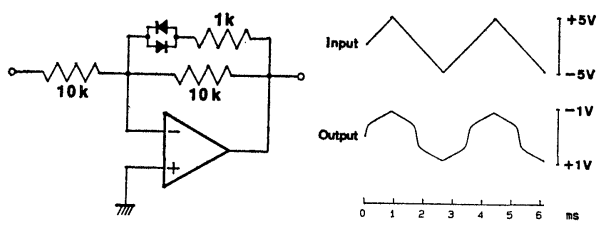

Fig. 4. An electric circuit diagram of a gain control unit and its response.
（加速度換算 $30 \mathrm{gal} ， 3 \mathrm{gal}$; 後述）が バースト的に入る.な拉，トリガーレ ベルは, 低感度センサーに対しては 25 30 gal に，また高感度センサーに 対しては 2.5 3 gal に設定した。

トリガーパルスはカウンターに入力 され，その結果得られるイベント数は

テレメータ装置に入力されている，ただし，振動レベルがトリガーレベル以下に下がってから $10 \mathrm{~ms}$ 経過する前に，再びそれがトリガーレベルを超える場合には，1個のトリガーパルスが 出続けるよらに設計した，従って，イベントが $10 \mathrm{~ms}$ 以内に群発したときも 1 個と数えられ る。また，突発的電気ノイズが計数されることもあるが，アクティブチャンネルとダミーチャ ンネルが同時に計数されるので，容易に識別できる.

トリガー時刻の前後 10 ないし $20 \mathrm{~ms}$ の波形データは，それぞれ，100 k ないし $50 \mathrm{kHz}$ サンプリングでウェーブメモリ(菊水社 WM 8700; 10 bit；1024 word/channel)に取り込ま れており，GPIB を介してパーソナルニンピュータ（NEC 社 PC-9801F3）に転送され， $\mathrm{CRT}$ 上に波形が表示されると同時に固定ディスクに記録される (約 1,000 個取込可能). こ 
れに要する時間は，1イベントあたり約 30 秒である（この 30 秒間に発生するイベントの波 形は観察できないが，その有無については，波形の取り込みとは独立に行われているイベント 計数の結果から知ることができる)。 また，固定ディスクに記録されたイベントの数はテレメ 一タ装置に入力されて扣り, 大学の端末装置で, 現地の固定ディスクに記録されているイベン トの個数を知ることがでさる．停電に対しては，その復旧後に，装置の初期化と観測再開とを 自動的に行らようにプログラムされている.

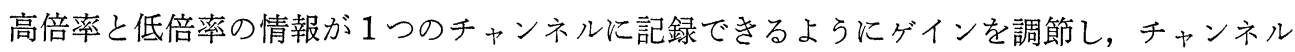
数を節約している (ゲインコントロール; Figs. 3, 4). 高倍率が必要であるのは信号の立ち上 がり付近の小信号部分だけであるから，振幅約 $600 \mathrm{mV}$ 以下の信号は減衰させずに 記録させ ている.この小信号の範囲は 8 bit 強に相当する分解能で観察できる。一方，低倍率が必要で あるのは大振幅の部分であるから，振幅 $600 \mathrm{mV} \sim 5 \mathrm{~V}$ の信号は $1 / 10$ に減衰させて記録させ ている.この範团は 9 bit 強に相当する分解能で観察できる．例えば， $10 \mathrm{~V}_{\mathrm{p}-\mathrm{p}}$ の三角波は Fig. 4 に示されている波形として固定ディスクにディジタル記録される.な挔，歪んだ形で 記録された波形は，ゲインコントロールの入出力特性（Fig. 4) をもとに，パーソナルコンピ ニータによって数值的に復元される.

\section{3. 突発的電気ノイズ対策}

突発的電気ノイズは, 観測対象としている振動と周波数帯域が重なるため, アナログフィル ターによって除去することはできない，後述する突発的電気ノイズ対策が施される以前は，固 定ディスクがノイズの波形データですぐ一杯になり，これを更新するために現地へ頻繁に赴か なければならなかった。また，記録された 1,000 個分のデータの中からごく少数のイベントを より分けなければならず，作業能率がきわめて低かった。

突発的な電気ノイズは，調査の結果，アンプに起因していることがわかった.アンプの内部 を調べた結果, 筐体が電気的に浮いているのに加え, 筐体内で入力信号線が単線のまま引き周 されているため，突発的ノイズを拾いやすいといらことがわかった．これらの点を改良すべく アンプに改造を加えた. その結果, 突発的なノイズの発生頻度が減り, 定常的なノイズレベル も下げることができた。

上記の改良によって突発的な, イズの頻度は減ったものの, 依然, 少なくはなかった。 そこ で，ダミーセンサー（抵抗器を銅箔で覆ったもの）を使用し，ダミーチャンネルには信号は現 れず電気ノイズだけが現れることを利用して，突発的電気ノイズによってはトリガーされない 機構を考えた。最初は，ダミーチャンネルからトリガー信号が出続けている間は，波形データ の取り达みもイベント計数も行わないという単純な機構にした. しかし，トリガーレベルはチ ヤンネルごとに微妙に異なるため, 突発的電気ノイズが全チャンネルに同時に現れても，トリ ガー信号が全チャンネル同時には出ない，場合によってはアクティブチャンネルから先にトリ ガー信号が出てしまうこともあったため，突発的電気ノイズを確実に除去することができなか った。 そこで, 次に, ダミーチャンネルの場合にはその出力がトリガーレベルを超えた瞬間に, またアクティブチャンネルの場合には $1 \mathrm{~ms}$ 遅れて, トリガー信号が出るように変更した。

Fig. 3 中の Delay が，この遅延を行う部分である.このようにして，突発的な電気ノイズが 発生したときには，ダミーチャンネルから，必ず先にトリガー信号が出るように改良された。 この改良によって, 1986 年 2 月に, 電気ノイズではほとんどトリガーされないシステムが, 
ようやく完成した。 この機構は $\mathrm{AC}$ 電源の瞬断等の大きい電気ノイズには無力であるが，そ の頻度は少ない.

\section{§3. 捉えられたイベント}

1985 年 2 月から 1985 年 7 月まではイベント計数のみが行われており, 降雨中とその前 後にはイベントが頻繁に計数されていた [小頻原・藤森 (1985)]. しかし, 1985 年 7 月から 開始した波形観測の結果, 降雨中とその前後に計数されるもののほとんどすべてが電気的ノイ ズであることがわかった. 7 月以前の観測で計数されていたものも恐らく全部が電気的ノイズ であると思われる。

観測点 1 では次に述べるイベント以外には，1985 年 7 月から 1986 年 2 月までの間に, 20 30 gal を超元る振動は記録されなかった．観測点 2 では，1985 年 7 月から同年 12 月ま での間に，20 30 gal を超える振動は 1 度も記録されなかった． 観測点 3 については $§ 4$ に 述べる．ただし，固定ディスクがデータで一杯になってしまったために，あるいは，突発的電 気ノイズが頻発していたために，イベントの有無がわからない期間は，1985 年 7 月から 1986 年 2 月までの間で延べ約 1 ケ月である.

1985 年 7 月から 1986 年 2 月の観測期間を通じて最大のイベントは，10月 21 日 0 時 8 分に最も岩体接触面に近い観測点 1 で捉えられた。 このイベントの卓越周波数は約 $3 \mathrm{kHz}$, 最大振幅は $50 \mathrm{gal}$ 以上であった (Fig. 5). 他のセンサー（すべて低感度）にはこのイベント は捉えられてはいなかった. 約 $7 \mathrm{~ms}$ 後に新たな振動が始まっているが, ウェーブメモリの容
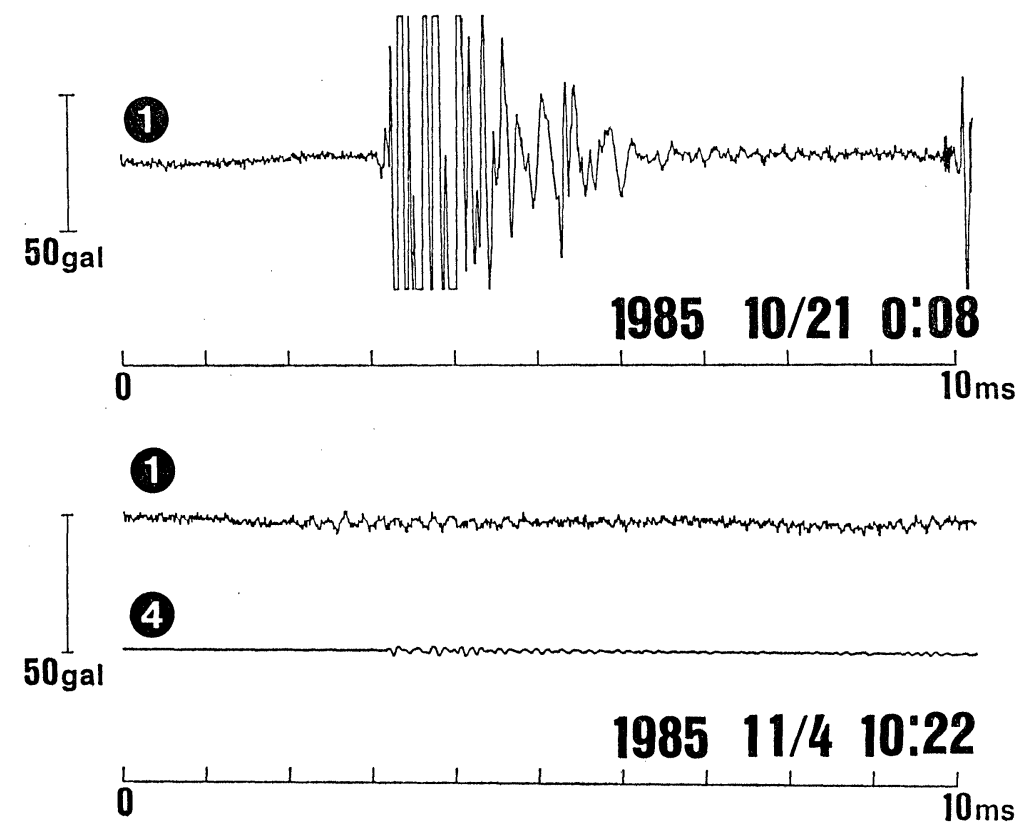

Fig. 5. Wave forms of the micro fracturings that occurred during an anomalous crustal deformation. These were observed at the locations shown in Fig. 2. by solid circles with the corresponding numerals. 


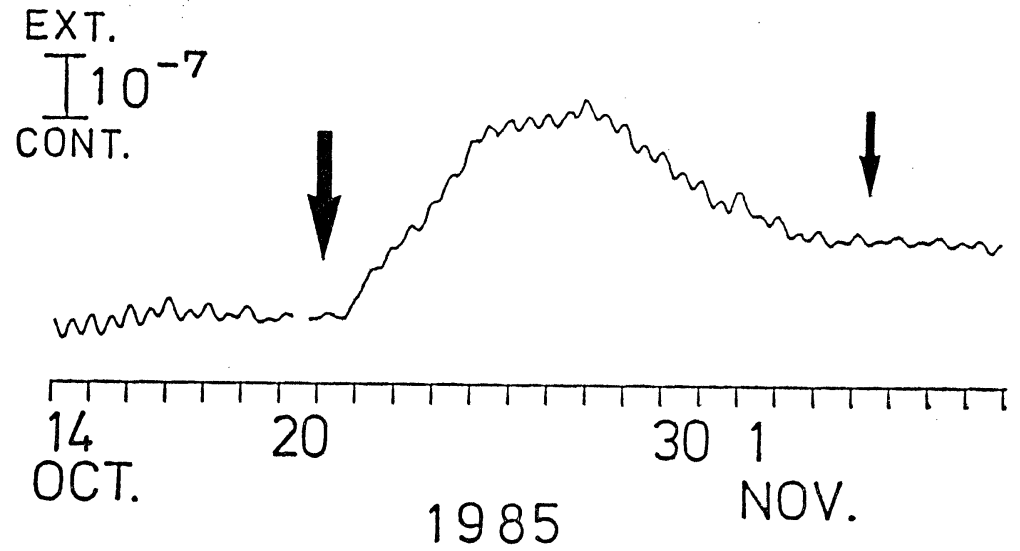

Fig. 6. The former part of an anomalous deformation observed by the extensometer No. 4 in October-November 1985. The micro fracturings in Fig. 5 were observed at the times pointed by arrows. [modified after FujImori et al. (1986)].

量不足のため, 以後の波形は記録されていない.一方，イベント計数では，このイベントによ るトリガー時刻前後（波形観測不能な 30 秒間を含む）には，1個しか記録されていないし たがって，トリガーレベルを超えたイベントは，10 ms を隔てずに群発していたか，あるいは

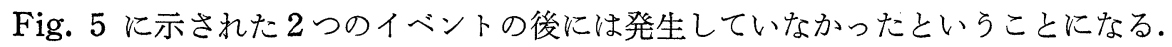

このイベントが発生した約 16 時間後の 10 月 21 日 16 時頃から伸縮計 4 番が異常な伸び を示し始め，10月 25 日 0 時頃まで伸び続けた (Fig. 6) [藤森・他 (1985)].

異常地殼変動が最も激しかった時期には間に合わなかったが，10月 25 日 15 時に観測点 4 に高感度センサーを設置し, トリガーレベル 3 gal の観測を開始した. その後, 11 月 4 日 に別のイベントが観測点 1 抢よび 4 で捉光られた (Fig. 5). 最大振幅は 10 月 21 日のイベ ントの $1 / 10$ 以下である.これは異常地殼変動が一時小康状態になったときに発生している (Fig. 6). その後, 最大振幅が 11 月 4 日なみのイベントが, 1 月 5 日と 8 日に観測点 1 および 4 で捉えられた。この時には異常地殼変動は観測されていない.

いずれのイベントも多くても 2 点でしか捉えられていない．また，2点で捉觉られている場 合でも， $S / N$ 比が悪いため位相を比較するのも困難であり，震源を推定することはできない.

\section{$\S 4$. 検 討}

今回捉えられたイベントを，これまでに述べた観測事実だけから，微小破壊と結論づけるの は時期尚早であろう，以下では，誤認する恐れがあるノイズ源について検討する.

雷雨時の電気ノイズの波形例を Fig. 7 (a) に示す. 図に示すように，短周期成分と長周期 成分が同時に現れているものと，図には示さないが，いずれかの成分しか現れていないものと がある. 次に，突発的電気ノイズの波形例を Fig. 7 (b) に示す。これらは，降雨中あるいは その前後に多く捉えられ，空電をアンプが拾ったと思われる [尾池 (1986)]. このような電気 ノイズは，ごくまれに降雨に関係ない時期に捉えられることもあった（例えば，10月 22 日 には，兵庫県北部は快晴であったにもかかわらず数十個捉えられている)。電気ノイズは全チ 


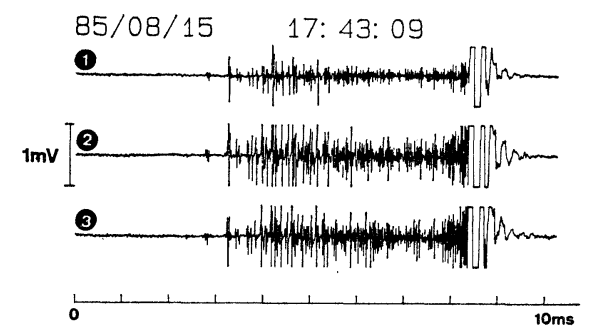

(a)

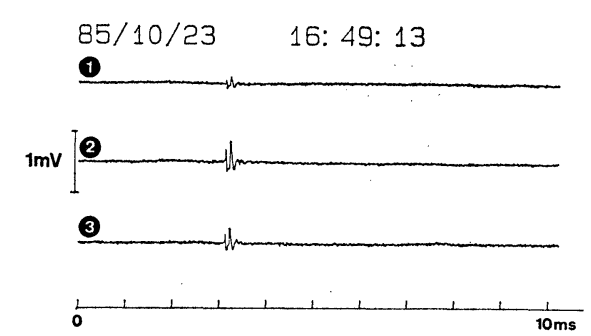

( b )

Fig. 7. Typical examples of electric noises. (a) Thunderbolts, (b) Atmospherics observed in sequence before and during rainfall. These were observed at the location shown in Fig. 2 by solid circles with the corresponding numerals.

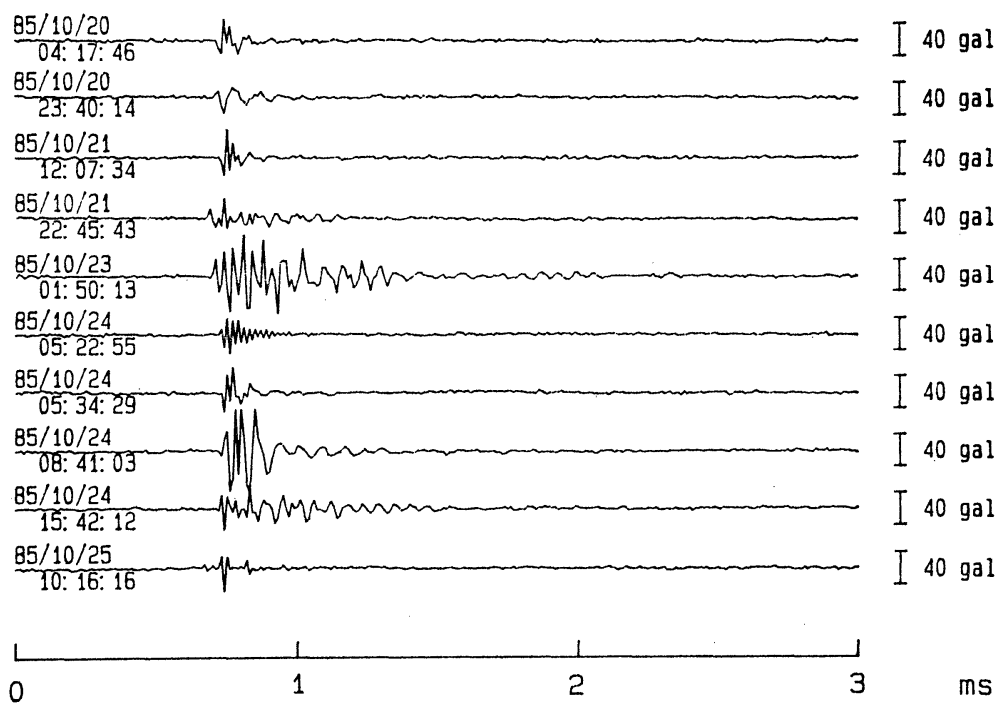

Fig. 8. Examples of the wave forms observed by the sensor No. 3 when the signal cable was not fixed firmly (see the location in Fig. 2).

ヤンネル同時に現れるので容易に識別できる．Fig. 5 と Fig. 7 に示された波形を比較する ことによっても，前節で述べたイベントが電気ノイズでないことがわかる.

観測点 3 付近の坑壁にはケーブルを固定するのに適当な凹凸が少なかったため，ケーブルの 固定が十分ではなかった．特に，センサー極近傍のケーブルが十分に固定されていない場合は， ケーブルが微小な岩盤を伝わる振動や空気中を伝わる音波に共鳴し，それが実際よりもかなり 大きい信号として記録されることがあった．例を Fig. 8 に示す．これらには，以下のような 特徴があった：

1）ケーブルの固定度が低くなるに従って発生頻度も高くなった,

2）ケーブルを固定し直したら発生しなくなった，

3）観測点 4 に設置した高感度センサーによっても，また観測点 3 から $1 \mathrm{~m}$ しか離れてい ない地点に一時的に設置した低感度センサーによっても，捉えることはできなかった。 
観測点 3 では，ちょらど伸縮計 4 番に異常地㲄変動が現れていた 10〜11 月に，このようなイ ベントが頻繁に捉えられていた，捉えられていたものは，何であるのか興味深いが，不明であ る.

観測点 3 のみで頻繁に捉えられた上記のイベントに対し，10月 21 日に観測点 1 で捉えら れたイベントや， 11 月 4 日，1 月 5 日拉よび 1 月 8 日に観測点 1 拈よび 4 で捉えられた イベントは，単発的であり，ヶーブル固定度も落ちていなかった．従って，これらは観測点 3 のみで頻繁に捉えられていたものとは性質が異なるものである.

水滴が岩盤に衝突したときの振動はどらであろらか。実験したところ, 水滴がセンサーを直 撃しないかぎり，トリガーレベルを超える振動は記録されなかった。センサーはオーバーハン グの陰に設置されているため, 水滴の直撃を受ける恐れはない. 従って, 今回捉えられたイべ ントは，規模や可能性から水滴が原因とは考光られない.

落石が岩盤に衝突した場合ならば，捉えられたイベントと同程度の規模の振動が発生しうる. しかし，捉兄られた規模の振動を発生させるためには，こぶし大の石が落下することが必要で ある.このよらな石が落ちていないか坑内を注意深く探したが，そのような石は見いだせなか った。 また，天井や坑壁にもそのような大きさの石がはがれ落ちた形跡も無かった。

イベントが捉えられた時, 生野地学観測室付近では微小地震 $(M>0)$ は発生していなかっ た [京都大学防災研究所附属鳥取微小地震観測所 (1986)]. また, 遠地の大地震も起こってい なかった [気象庁地震火山部 (1986)]. 従って, 今回捉えられたイベントは, 地震そのものの 震動でもなく，その震動に励起されたものでもない.

誤認する恐れがあるノイズ源は上記以外にはないと考えられる.

以上の検討の結果，今回捉兄られたイベントは，これまでに述べた原因では説明できず，自 然極微小破壊である可能性が高いと考兄られる.

\section{§5. まとめと今後の課題}

1985 年 7 月から 1986 年 2 月までの 8 ケ月間, イベント計数と波形観測とを行った結果, 自然極微小破壞によって発生したと思われる振動を 4 例捉光ることができた. 1985 年 10 月 21 日のイベントは岩体接触面に最も近いセンサーのみに, 他のイベントもこのセンサーと次 に近いセンサーとによって捉えられたものであった。 これらの振動は, 波形や発生頻度, 到達 時刻差に抢いて，他の原因によって発生するノイズや振動とは明かに異なるものであった。

自然極微小破壊と地殼変動との同時並行観測の結果，幸運にも，観測期間を通じて最も大き い極微小破壊と異常地殼変動とを汸ぼ同時期に捉えることができた。これらは全く無関係では ないと思われる，しかし，多くても2 点でしか振動を捉えることができず，震源決定はできな かった. また, 異常地殼変動が最も激しかった 10 月 $21 \sim 24$ 日には, 高感度センサーの設置 が間に合わず，最大振幅 30 gal より小さいイベントがこの期間に発生していたかどうかはわ からなかった。

今回の観測結果だけから異常地殼変動の原因を解明することはできなかった。システムの検 知能力を上げて自然極微小破壊の観測を続け，データを増やすことが重要である. 


\section{謝辞}

三菱金属 (株) 生野工場の各位，株式会社シルバー生野故横山圭一支配人お゙よび西村米一現支 配人ならびに藤原栄治，藤原光幸両氏を始め同職員の方々には，観測の便宜をはかって頂きま した. 元京都大学理学部地震予知地域観測センター三木晴男教授には多くの支援を頂きました. 京都大学理学部地震予知観測地域センター行竹英雄助手には, 予備観測に際して測器を貸して 頂き，また，微小破壞観測の手ほどきと多くの助言を頂きました．京都大学理学部中川一郎助 教授および田中 豊講師には有益な助言を頂きました. 京都大学防災研究所尾池和夫助教授に は有益な示惨を頂きました．京都大学防災研究所岸本兆方教授ならびに同研究所附属鳥取微小 地震観測所渋谷拓郎助手には地震データを提供して頂きました。予備観測とセンサー設置時に は京都大学理学部地球物理学教室の田部井隆雄・福田正浩両氏をはじめ院生諸氏の助力を頂き ました。これらの方々に，ここに心から扮礼を申し上げます。

\section{文献}

藤森邦夫・田部井隆雄・田中 豊, 1984, 1984 年 5 月 30 日山崎断層地震前後の生野観測室に打汓る 地殼変動, 地震学会講演予稿集, No. 2, 9 .

藤森邦夫・田部井隆雄・田中 豊, 1985, 生野地学観測室に打汀る地震に先行する異常地殼変動, 地 震学会講演予稿集, No. $1,264$.

藤森邦夫・田部井隆雄・田中 豊, 1986, 生野地学観測室に抢ける異常地殼変動と地震 (本震・余震) との関連について, 地震学会講演予稿集, No. 1,261 .

飯尾能久, 1984。余震を伴う微小破壊, 地震, $2,37,599-606$.

気象庁地震火山部, 1985. 地震火山概況, No. 259, 11.

京都大学防災研究所附属鳥取微小地震観測所, 1986, 私信.

小笠原 宏・藤森邦夫, 1985, 生野地学観測室に打ける自然極微小破壊の観測について, 地震予知 「きんき・けいはんしん」会報，7，4-17。

尾池和夫, 1986, 私信.

田部井隆雄・藤森邦夫・田中 豊, 1985, 生野に抢活地殻変動の連続観測 $(1977 \sim 1983)$, 測地学会 誌, 31, 189-201. 